\title{
Evaluation of trace metals (cadmium, chromium, copper and zinc) in tissues of a commercially important fish (Leporinus obtusidens) from Guaíba Lake, Southern Brazil
}

\author{
Silene de Carvalho Costa and Sandra Maria Hartz ${ }^{*}$ \\ Universidade Federal do Rio Grande do Sul; C.P.: 15007; 91501-970; Porto Alegre - RS - Brasil
}

\begin{abstract}
Concentrations of $\mathrm{Cd}, \mathrm{Cr}, \mathrm{Cu}$ and $\mathrm{Zn}$ were determined in liver and muscle of Leporinus obtusidens. During 2003, the fishes $(N=54)$ were sampled from three sites along Guaíba Lake (north, central and south zones). The hypotheses tested assumed that there were differences in the location and date as to levels of contamination, association between the trace metal content in the fishes and size, and that the sex influenced metal accumulation. Possible risks of contaminated fish consumption to human health were also evaluated. The level of mean

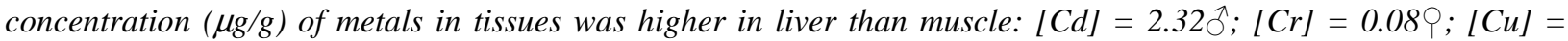
$30.82+$ and $[\mathrm{Zn}]=97.77 \bigcirc$. The results showed differences between the local and date sampling for all metals except $\mathrm{Cr}$. Metal content was higher in the warmer than colder seasons and in the central zone than at other points. Significant sexual differences were detected for $\mathrm{Cd}$ and $\mathrm{Zn}$ and there were positive associations between the size and metal concentrations for $\mathrm{Cu}$ and $\mathrm{Zn}$. The concentration levels of metals in muscle tissue showed that the fish samples did not offer risks to human health.
\end{abstract}

Key words: trace metals, Leporinus obtusidens, environmental contamination, Guaíba Lake, Southern Brazil

\section{INTRODUCTION}

Lakes are economically and ecologically important for adjacent cities due to their potential for intensive recreational activities and fishing. However, they may also present high levels of contamination by agricultural, urban and industrial pollutants. The input of trace metals into the aquatic food chain frequently occurs by direct consumption of the contaminated biota. Another potential form of contamination is the uptake by epithelial absorption (i.e., the gills, in the case of fish), considered as a non-dietary route of metal intake (Burger et al., 2002). Metals like copper
$(\mathrm{Cu})$ and zinc $(\mathrm{Zn})$, in small amounts, are essential for metabolic processes and are assimilated by the organisms over time; others, such as mercury $(\mathrm{Hg})$, chromium $(\mathrm{Cr})$ and cadmium $(\mathrm{Cd})$ have an unknown role in biological systems and have, therefore, been extensively studied (Bidone et al., 1997; Burger et al., 2001; Tomazelli et al., 2003; Burger and Gochfeld, 2005).

Environmental assessments in aquatic ecosystems may be conducted in water, organisms or sediments. Each of these components provides a partial image of metal occurrence within the whole system. However, according to Marcovecchio and Moreno (1993), the advantage of studying the

*Author for correspondence: sandra.hartz@ufrgs.br 
organisms is that results reflect the bioavailability of pollutants in the system and, consequently, could help showing the true degree of pollution in the environment assessed. As a result of their ecological characteristics (life time, type of diet, distribution in the biotope) and their economic usefulness, fishes are widely used as biological monitor variables to detect environmental levels of anthropogenic pollutants (Bryan and Langston, 1992; Canli and Furness, 1993; Kalay and Canli, 2000). Moreover, fishes are at the end of the aquatic food chain and may accumulate metals and pass them on to human beings when consumed as food, causing chronic or acute diseases (Förstner and Wittmann, 1981; Khan and Weis, 1993; Adeyeye et al., 1996; Burger and Gochfeld, 2005). Information on trace metal concentrations in commercial fish is important for environmental management as well as to evaluate the possible risk of fish consumption for human health. Liver and muscle are usually used as the target tissues for the analysis of metal concentrations. Studies carried out with different fish species have shown that trace metals accumulate mainly in metabolic organs such as the liver, where metals are stored for detoxication through metallothioneins (Carpene and Vasak, 1989; Kargin and Erden, 1991; Hogstrand and Howx, 1991). Although muscle is not an active tissue for accumulating the heavy metals, except mercury/MeHg (Ünlu et al., 1996; Bidone et al., 1997; Roméo et al., 1999; Yilmaz, 2003), the study of potential metal accumulation in this part of the body is justified because it is the edible part of the fish for humans. In Brazil, few studies have evaluated metal levels in inland water fish, although it is a country with large water resources and a great ichthyic diversity (Vari and Malabarba, 1998). Exceptions can be found for the evaluation of $\mathrm{Hg}$ levels in Amazonian fishes (Bidone et al., 1997; Castilhos et al., 2001) and a few other studies in the southeastern region of the country (Rocha et al., 1985; Jordão et al., 1997). For the southern region of Brazil, only the studies by Raya-Rodriguez and Mozeto (1995) and Silvano and Raya-Rodriguez (2003) can be mentioned.

Porto Alegre city, in southern Brazil, encompasses a large water body (Guaíba Lake) that receives industrial and organic wastes. The hydrographic basin, to which the lake belongs, is one of the largest industrial centers of southern Brazil and has a population of over one million inhabitants. Since the lake is the source of water supply for the surrounding cities, beginning in the 1970s, its water has been constantly evaluated by the municipal administration (Bendati et al., 2000), but the metal levels have not been assessed. Laybauer (2002) analyzed trace metal contamination in Guaíba Lake sediments, and divided the water body according to the sedimentation dynamics into three different sectors (north, central and south), with a moderate level of contamination from north to south (Laybauer and Bidone, 2001).

The most important fish species in the lake is Leporinus obtusidens (Anostomidae), commonly known as "piava", which is very important for fisheries in the region due to its size and taste. The species is omnivorous and consumes mainly plant matter, mollusks and sediments (Hartz et al., 2000). Mollerke et al. (2002 and 2003) conducted a study in which they evaluated the $\mathrm{Hg}$ and arsenic (As) concentrations in L. obtusidens in the lake, indicating levels in muscle below the limit tolerated by Brazilian authorities for fish products. Although it was an important result, the authors did not verify the spatial or temporal variation in the levels of the concentrations of metals.

With the perspective of continuing to perform the evaluations of metal contamination in the fishes in the study region, the purpose of this work was to evaluate cadmium $(\mathrm{Cd})$, chromium $(\mathrm{Cr})$, copper $(\mathrm{Cu})$ and zinc $(\mathrm{Zn})$ levels in the muscle and liver tissue of Leporinus obtusidens from Guaíba Lake and to investigate the relationship between the fish size (standard length), sex, season and location of capture concerning these metal levels. Furthermore, the non-carcinogenic risk related to the consumption of contaminated fish by a hypothetical population was calculated. The metals investigated herein were chosen because they were likely discharges of the kind of industries present along the hydrographic basin (leather tanning and finishing, petrochemicals, organic wastes of water treatment) (Laybauer, 2002; Rodrigues and Formoso, 2005).

\section{MATERIAL AND METHODS}

Guaíba Lake is located in Porto Alegre City, southern Brazil $\left(30^{\circ} 10^{\prime} \mathrm{S}-51^{\circ} 15^{\prime} \mathrm{W}\right)$. It is a lake where four rivers meet, creating a connection with Patos Lagoon. The whole system belongs to Guaíba hydrological basin: Jacuí, Sinos, Caí and Gravataí rivers, Guaíba Lake and Patos Lagoon. 
The Guaíba Lake area is around $470 \mathrm{~km}^{2}, 50 \mathrm{~km}$ long and 0.9 and $19 \mathrm{~km}$ wide. The mean depth is 2 $\mathrm{m}$, reaching around $12 \mathrm{~m}$ in the navigation channel (Menegat et al., 1998). According to Koeppen's climatic classification, the Guaíba Lake region is considered Cfa (subtropical), with well-distributed rainfall throughout the year, an annual mean temperature around $19^{\circ} \mathrm{C}$ and total mean precipitation around $1324 \mathrm{~mm}$ (Laybauer and Bidone, 2001). The city of Porto Alegre lies on the eastern side of the lake, where most organic waste is discharged. There are smaller towns on the western side.
Leporinus obtusidens individuals $(\mathrm{N}=54)$ were collected (always on the eastern side of the lake) during 2003 at three different sites of Guaíba Lake: North Point, Central Point (in front of Porto Alegre City) and South Point (Fig. 1), the same regions defined by Laybauer (2002). The individuals were immediately frozen and stored at $-5^{\circ} \mathrm{C}$ in a freezer until dissection. During dissection in laboratory, the specimens were weighed and their standard length was measured; a portion of $20 \mathrm{~g}$ of both muscle fillets and liver were removed from each fish.

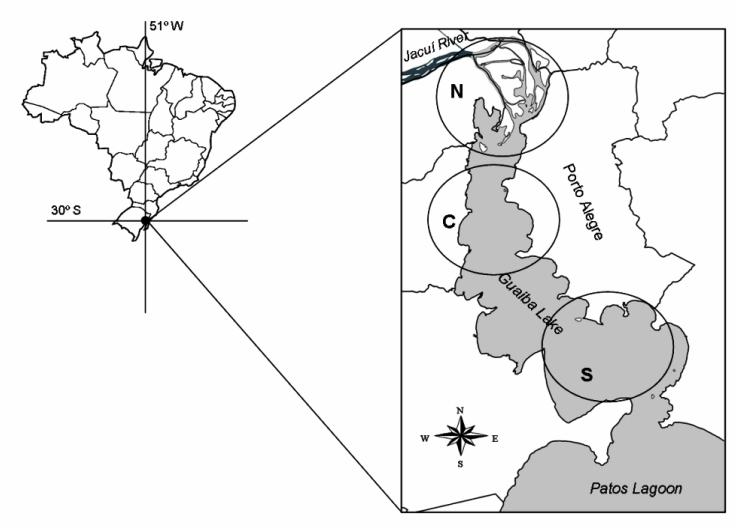

Figure 1 - Location of Guaíba Lake, Brazil, and its respective sampling sites: $\mathrm{N}=$ North; $\mathrm{C}=$ Central and $\mathrm{S}=$ South $($ Scale: $1 \mathrm{~cm}=14 \mathrm{~km})$.

Tissues were dried in an oven at $60^{\circ} \mathrm{C}$ to constant weight. After that, they were digested with $2 \mathrm{ml}$ $\mathrm{HNO}_{3}(65 \%$ Suprapur) in Teflon bombs placed into a microwave digestion system (CEM-MDS 2000). After cooling, they were transferred to a 50 $\mathrm{ml}$ volumetric flask and rinsed with triple distilled water. For each five samples analyzed, one analytical blank was prepared as a control in the same manner, but without tissue samples, to check for possible contamination of the samples. Cadmium $(\mathrm{Cd})$, chromium $(\mathrm{Cr})$ and copper $(\mathrm{Cu})$ concentrations were measured using a simultaneous multielement atomic absorption spectrometer (GFAAS), SIMAA 6000 Perkin Elmer. Zinc $(\mathrm{Zn})$ concentrations were measured using a flame absorption spectrophotometer Perkin Elmer (model 3300). The results were expressed in micrograms of metal per dry weight gram of fish $(\mu \mathrm{g} / \mathrm{g})$. The detection limits, expressed as $\mu \mathrm{g} / \mathrm{g}$, were as follows: $\mathrm{Cd}=0.012, \mathrm{Cr}=0.012 ; \mathrm{Cu}=$ 0.083 and $\mathrm{Zn}=0.833$. The results were validated according to ISO 17025 accreditation (ABNT,
2005). Quality assurance was related to internal (use of blanks, measurement standards, spiked samples and replicate analysis and statistical control charts) and external quality control (participation in inter-laboratory comparison and proficiency testing programmers obtained from the National Institute of Standards and Measure, INMETRO) with Certificate of Proficiency in trace metal analysis.

The results were expressed as mean \pm standard deviation. The individuals were compared, for each metal, in relation to sex, date (hot period: spring and summer; cold period: fall and winter) and sampling station (north, central and south). Data were submitted to analyses of variance with randomization testing (Manly, 1997). The test criterion was the sum of squares between the groups (Qb statistic, Pillar and Orlóci, 1996), computed on Euclidian Distances between the sampling units, using $\alpha<0.05$. All analyses of variance were performed using the statistical software MULTIV v. 2.3 (Pillar, 2004). 
Additionally, the simple linear regression test was used to check significant relationships between trace metal concentrations and individual size (Zar, 1984).

To determine the risks for humans associated with fish consumption, metal concentrations in muscle tissues $(\mu \mathrm{g} / \mathrm{g})$ were compared to the maximum permissible concentrations (MPC) as stated by the Brazilian Ministry of Health (1997). Additionally, the margin of exposure (MOE) was calculated in order to evaluate the species-specific risk from consumption of fish contaminated with individual compounds (Watanabe et al., 2003):

$$
M O E=\frac{M C C \times C R}{B W \times R f D}
$$

where $M C C$ was the species-specific mean chemical concentration $(\mathrm{mg} / \mathrm{kg}), C R$ was the consumption rate assumed to be $0.03 \mathrm{~kg} /$ day, $B W$ was the human body weight assumed to be $70 \mathrm{~kg}$ and $R f D$ was the reference dose for the specific constituent in $\mathrm{mg} / \mathrm{kg}$ (EPA, 2001). A MOE superior to 1 indicated the exposure to a dose higher than the safe daily dose for chronic noncarcinogenic effects. The reference dose factors adopted by the United States Environmental
Protection Agency (EPA, 2001) and used in this study were: $\mathrm{Cd}=0.001, \mathrm{Cr}=1.5, \mathrm{Zn}=15$; for copper, there is no information (Fernandes et al., 1994).

\section{RESULTS}

Body size distribution showed that size differences among the females and males captured were low with the largest female attaining $424 \mathrm{~mm}$ $(1,769.89 \mathrm{~g})$ and male $352 \mathrm{~mm}(1,190.27 \mathrm{~g})$ of total body size. Metal concentrations found in the tissues of $L$. obtusidens varied considerably and for all metals were lower in muscle than in liver (Fig. 2). For $\mathrm{Cd}$ and $\mathrm{Cr}$, the concentrations were below the minimum limit of detection for the males.

Significant differences in metal accumulation were found between the females and males only for the concentrations found in the liver for $\mathrm{Cd}(\mathrm{P}=0.03)$ and in the muscle for $\mathrm{Zn}(\mathrm{P}=0.04)$, the latter being higher in the males (Fig. 3). In both sexes, the mean concentration of the tested elements followed the sequence $\mathrm{Zn}>\mathrm{Cu}>\mathrm{Cd}>\mathrm{Cr}$.
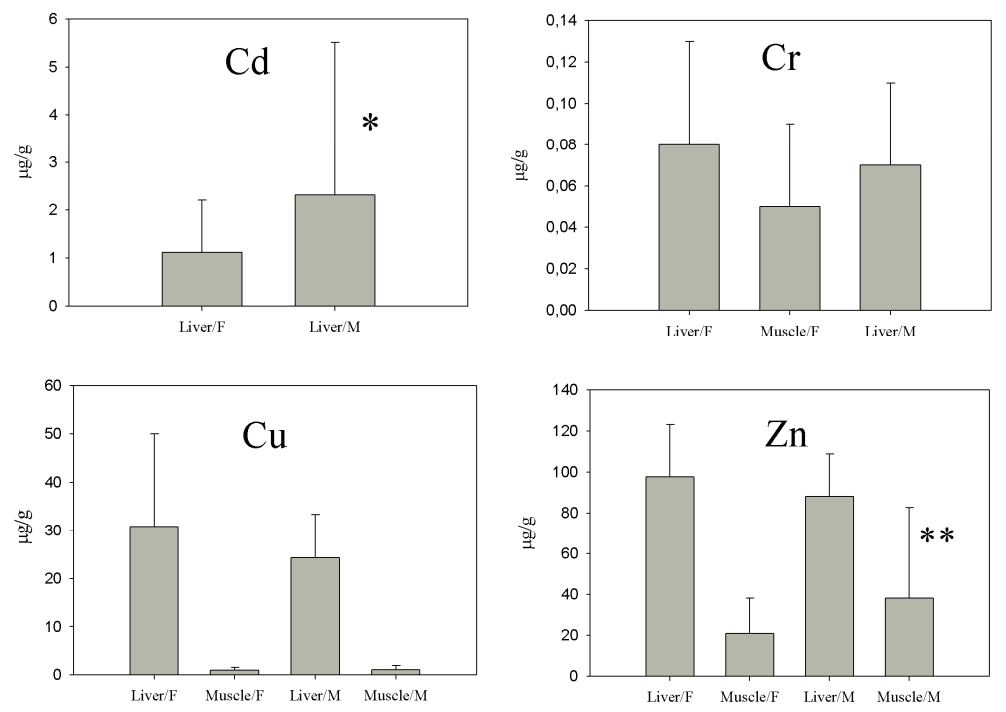

Figure 2 - Mean concentration $(\mu \mathrm{g} / \mathrm{g})$ of metals in tissues of Leporinus obtusidens caught in Guaíba Lake, Brazil, during 2003. Females (F): N=35, standard length ranges $=282$ $424 \mathrm{~mm}$, weight ranges $=484-1,770 \mathrm{~g}$. Males $(\mathrm{M}): \mathrm{N}=19$, standard length ranges $=280$ $352 \mathrm{~mm}$, weight ranges $=493-1,190 \mathrm{~g}$. Mean values significantly different between the same tissue: $* \mathrm{P}=0.039, * * \mathrm{P}=0.041$. For $\mathrm{Cd} /$ muscle and $\mathrm{Cr} / \mathrm{muscle} / \mathrm{males}$ the concentrations were below detection limits 
There was a significant association between the size and metal levels for $\mathrm{Cu}\left(\mathrm{R}^{2}=0.22 ; \mathrm{P}=0.004\right)$ and $\mathrm{Zn}\left(\mathrm{R}^{2}=0.14 ; \mathrm{P}=0.02\right)$ in the liver of the females (Fig. 3). As for the other metals and mainly for muscle tissue, the concentrations of $\mathrm{Cr}$, $\mathrm{Cd}, \mathrm{Cu}$ and $\mathrm{Zn}$ were independent of body size.

Table 1 shows the mean levels of metal concentrations per site and date. Since there was a significant difference between the concentrations found for the males and females only for $\mathrm{Cd} /$ /iver and $\mathrm{Zn} /$ muscle, all the other tests were brought together in respect to the sex. For Cd, there was interaction between the factors date and site, and there were higher concentrations in the central region and during the warm season $(P=0.042)$ for the females. The central region of the lake and the warm period of the year were also factors of influence on the $\mathrm{Cu}$ levels (liver, $\mathrm{P}=0.027$ and muscle, $\mathrm{P}=0.034$ ), and $\mathrm{Zn}$ (liver, $\mathrm{P}=0.032$ ). Chromium concentrations did not vary according to site and temporal patterns.

Regarding the risk of fish consumption on human health, the mean concentrations (wet weight) found were low compared to the permitted maximum concentrations and margin exposure (Table 2).

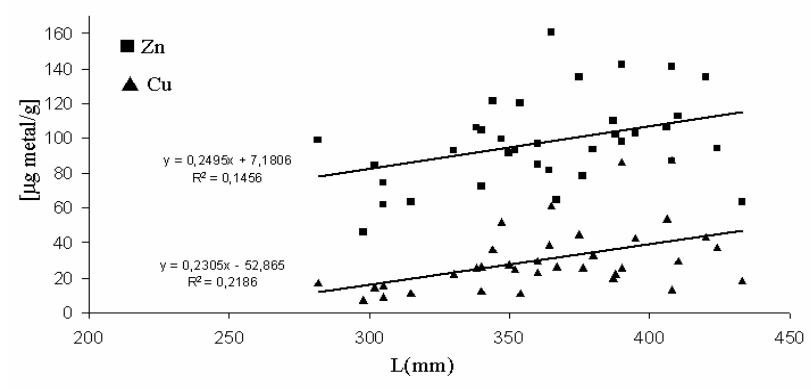

Figure 3 - Simple linear regression between $\mathrm{Zn}$ and $\mathrm{Cu}$ liver concentration $(\mu \mathrm{g} / \mathrm{g})$ and standard length (L) estimated for Leporinus obtusidens in Guaíba Lake, Brazil, during 2003.

Table 1 - Standard length ranges $(\mathrm{L})$, number of males $\left({ }^{\top}\right)$ and females $(q)$ and mean metal concentration $(\mu \mathrm{g} / \mathrm{g})$ in liver (1) and muscle (m) of Leporinus obtusidens from Guaíba Lake, Brazil, from different date and sampling sites, during 2003.

\begin{tabular}{|c|c|c|c|c|}
\hline \multirow{2}{*}{$\begin{array}{c}\text { Sampling sites } \\
\text { North }\end{array}$} & \multicolumn{2}{|c|}{ Spring and Summer } & \multicolumn{2}{|c|}{ Fall and Winter } \\
\hline & $3{ }^{\hat{O}} \mathrm{~L}=287-304 \mathrm{~mm}:$ & $7 q \mathrm{~L}=298-410 \mathrm{~mm}:$ & $3 \hat{\jmath} \mathrm{L}=335-346 \mathrm{~mm}:$ & $7 \circ$ L $=302-390 \mathrm{~mm}:$ \\
\hline $\mathrm{Cd}$ & $0.22(1)$ & $0.94(1)^{*}$ & $0.85(1)$ & $0.68(1)$ \\
\hline $\mathrm{Cr}$ & $0.08(1)$ & $0.04(1) ; 0.03(\mathrm{~m})$ & $0.04(1)$ & $0.10(\mathrm{l}) ; 0.04(\mathrm{~m})$ \\
\hline $\mathrm{Cu}$ & $17.27(1)^{* * ;} 0.56(\mathrm{~m}) \dagger$ & $23.29(1) * * ; 0.91(\mathrm{~m}) \dagger$ & $23.73(1)^{* * ;} 0.71(\mathrm{~m}) \dagger$ & $22.06(1) * * ; 0.95(\mathrm{~m}) \dagger$ \\
\hline $\mathrm{Zn}$ & $81.67(\mathrm{l}) \ddagger ; 19.37(\mathrm{~m})$ & $82.64(\mathrm{l}) \neq ; 23.56(\mathrm{~m})$ & $81.43(\mathrm{l}) \ddagger ; 14.33(\mathrm{~m})$ & $94.21(\mathrm{l}) \ddagger ; 15.2(\mathrm{~m})$ \\
\hline Center & $7 \circlearrowleft \mathrm{L}=300-336 \mathrm{~mm}:$ & $3 \bigcirc \mathrm{L}=354-365 \mathrm{~mm}:$ & $3 \hat{\mathrm{O}} \mathrm{L}=324-352 \mathrm{~mm}:$ & 7 ㅇ $\mathrm{L}=344-424 \mathrm{~mm}:$ \\
\hline $\mathrm{Cd}$ & $4.35(1)$ & $3.29(1)^{*}$ & $1.02(1)$ & $1.23(1)$ \\
\hline $\mathrm{Cr}$ & $0.07(1)$ & $0.05(1)$ & $0.12(1)$ & $0.07(1) ; 0.03(\mathrm{~m})$ \\
\hline $\mathrm{Cu}$ & $29.47(1)^{* * ;}, 1.64(\mathrm{~m}) \dagger$ & $31.93(\mathrm{l})^{* * ;}, 1.47(\mathrm{~m}) \dagger$ & $23.07(1)^{* *} ; 0.85(\mathrm{~m}) \dagger$ & $49.6(1)^{* * ;} 0.8(\mathrm{~m}) \dagger$ \\
\hline $\mathrm{Zn}$ & $104.44(\mathrm{l}) \neq ; 75.83(\mathrm{~m})$ & $126.0(\mathrm{l}) \ddagger ; 49.57(\mathrm{~m})$ & $70.93(1) \ddagger ; 17.9(\mathrm{~m})$ & $111.1(\mathrm{l}) \ddagger ; 17.73(\mathrm{~m})$ \\
\hline South & $2 \lesssim \mathrm{L}=280-295 \mathrm{~mm}:$ & 7 ㅇ $\mathrm{L}=282-406 \mathrm{~mm}:$ & 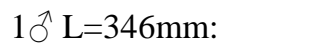 & $4+\mathrm{L}=350-420 \mathrm{~mm}:$ \\
\hline $\mathrm{Cd}$ & $0.84(1)$ & $0.9(1)^{*}$ & $1.55(1)$ & $0.81(1)$ \\
\hline $\mathrm{Cr}$ & $0.07(1)$ & $0.11(\mathrm{l}) ; 0.1(\mathrm{~m})$ & $0.02(1)$ & $0.06(1) ; 0.03(\mathrm{~m})$ \\
\hline $\mathrm{Cu}$ & $18.25(1)^{* *} ; 0.7(\mathrm{~m}) \dagger$ & $29.04(\mathrm{l})^{* * ;} ; 1.14(\mathrm{~m}) \dagger$ & $26.1(1)^{* *} ; 0.9(\mathrm{~m}) \dagger$ & $28.62(1)^{* *} ; 0.62(\mathrm{~m}) \dagger$ \\
\hline $\mathrm{Zn}$ & $81.9(\mathrm{l}) \ddagger ; 13.2(\mathrm{~m})$ & $89.94(1) \neq ; 14.56(\mathrm{~m})$ & $78.3(1) \neq ; 15.3(\mathrm{~m})$ & $102.13(\mathrm{l}) \neq ; 15.88(\mathrm{~m})$ \\
\hline
\end{tabular}

Mean values significantly different: $\mathrm{Cd}={ }^{*}$ season $\mathrm{x}$ sampling site/liver, $\mathrm{P}=0.042 ; \mathrm{Cu}={ }^{* *}$ sampling site/liver, $\mathrm{P}=0.027$, and $\dagger$ season/muscle, $\mathrm{P}=0.034 ; \mathrm{Zn}=\ddagger$ sampling site/liver, $\mathrm{P}=0.032$. 
Table 2 - Mean concentration of metals $(\mu \mathrm{g} / \mathrm{g})$, maximum permissible concentrations (MPC) ( $\mu \mathrm{g} / \mathrm{g}$ ) and margin of exposure (MOE) in muscle of the Leporinus obtusidens caught the Guaíba Lake, Brazil, during 2003.

\begin{tabular}{lccc}
\hline Metal & Concentrations & MPC & MOE \\
\hline Cadmium & $0.012^{*}$ & 1.0 & $5.0 \times 10^{-3}$ \\
Chromium & $0.05 \bigcirc$ & 0.1 & $1.4 \times 10^{-5}$ \\
Copper & $1.12 \overbrace{}^{\top}$ & 30.0 & - \\
Zinc & $38.28 \overbrace{}^{-1}$ & 50.0 & $1.1 \times 10^{-3}$ \\
\hline
\end{tabular}

*limit detection value.

\section{DISCUSSION}

Levels of the essential metals $(\mathrm{Cu}, \mathrm{Zn})$ in the fish sampled were higher than those of non-essential metals (Cd, Cr). Laybauer (2002) established the background level of metals studied for the Guaíba Lake sediments in $\mu \mathrm{g} / \mathrm{g}(\mathrm{Cd}=0.3 ; \mathrm{Cr}=21 ; \mathrm{Cu}=$ 27 and $\mathrm{Zn}=110)$. Considering that L. obtusidens fed close to the sediment (Hartz et al, 2000), only $\mathrm{Cd}$, among the metals analyzed, was found in values considered high in the liver of this species. In fishes, $\mathrm{Cd}$ can cause very adverse effects because this metal blocks sulfhydryl groups in enzymes and competes for binding sites that are essential for normal enzyme functioning (Allen, 1994). Regarding the two organs considered, all the metal concentrations were higher in the liver than in muscle. Numerous studies have shown that concentrations of $\mathrm{Cu}, \mathrm{Cd}$ and $\mathrm{Zn}$ are usually elevated in teleost liver when compared to muscle tissue (Hellou et al., 1992; Raya-Rodriguez and Mozeto, 1995; Swales et al., 1998; Gbem et al., 2001; Moiseenko and Kudryavtseva, 2001; Canli and Atli, 2003). Despite their antagonistic biochemical roles, all three metals are capable of inducing the synthesis of metal binding proteins such as metallothioneins (MT) in hepatic tissue. The in vitro affinity for MT decreases in the hierarchical sequence $\mathrm{Hg}^{+2}, \mathrm{Ag}^{+}, \mathrm{Cu}^{+}, \mathrm{Cd}^{+2}, \mathrm{Zn}^{+2}$. The low concentrations of metals in the muscles of the fish species examined in this work could reflect the low levels of these binding proteins in the muscle tissue (Allen-Gil and Martynov, 1995).

Some studies have shown a relationship between the metal accumulation and sex (Al-Yousuf et al., 2000). The nature of hormones and the available number of active sites in the proteins and cytochrome P-450 in the females may be determinant factors to this relation (Jargensen and Petersen, 1994), indicating the differences in the metabolic activities between the sexes. The differentiated levels of $\mathrm{Cd}$ and $\mathrm{Zn}$ concentration levels found for $L$. obtusidens might reflect a difference in the detoxifying capacity of these elements, higher in the females, which would account for the higher levels found in the males.

Although the age of the L. obtusidens individuals sampled was not evaluated, it was assumed that the larger individuals had a longer time of exposure to the metals in the lake. Castilhos et al. (2001) found a positive linear relationship between the growth rate of Cichla ocellaris (Cichlidae) and the $\mathrm{Hg}$ concentrations in muscle. For the metals studied in this work, relations were only found between $\mathrm{Cu}$ and $\mathrm{Zn}$ in the liver, and this behavior was not indicated for the muscle tissue. Some authors found that $\mathrm{Zn}$ and other essential elements usually did not increase in concentration with age or size because they were under physiological control (Evans et al., 1993; Andres et al., 2000). On the other hand, the increase in zinc and copper liver content as L. obtusidens grew was likely due to the fact that this metal could be bioaccumulated by some fish species without any toxic effect (Sternlieb, 1980). Other studies have also demonstrated a positive relationship between $\mathrm{Cu}$ concentration and body size (Mastala et al., 1992; Linde et al., 1998; Farkas et al., 2003). However, the lack of association in L. obtusidens for $\mathrm{Cd}$ and $\mathrm{Cr}$ indicated that this strategy would not work for all the metals. This lack of association between the metals studied and fish size could also be explained by the small differences in the sizes of the fishes sampled, since all the individuals were adults.

Although sample number was low, the statistical analyses indicated a higher concentration of $\mathrm{Cd}$, $\mathrm{Cu}$ and $\mathrm{Zn}$ in the liver tissue of L. obtusidens captured in the central region of the Guaíba Lake. The $\mathrm{Cr}$ concentrations were low and did not vary from one place to another. For chromium concentrations, generally, there is little evidence of accumulation in fishes (Phillips, 1977; Jordão et al., 1997; Burger and Gochfeld, 2005). Despite 
Laybauer (2002) presented a decreasing gradient of metals contamination in sediment from north to south, the highest concentrations of metals were found in the fishes collected in the Central Point of Guaíba Lake. This could be due to the higher concentration of organic material in the sediment close to Porto Alegre, where large amount of sewage was discharged. Water quality analyses performed by the municipal government (Bendati, 2000) recorded a worsening of water quality in the eastern region of the lake in front of the Porto Alegre city, the fecal coliforms and oxygen conditions were indirectly responsible for the reduction in this quality, where other parameters (such as $\mathrm{pH}$ ) did not influence the evaluation. Furthermore, Laybauer (2002) indicated that the central region of the lake was the most affected by the organic contaminants and, consequently, route of the metals in sediments (Laybauer and Bidone, 2001).

Date differences in the $\mathrm{Cd}$ and $\mathrm{Cu}$ concentrations were also observed in his study. Zayed et al. (1994) found higher metal content in summer than in autumn in the fishes and attributed this difference to the higher respiratory rate (high flux of water through the gills due to the low dissolved oxygen content in the water) and higher feeding rate on the plants and grasses during the summer. This could also happen in Guaíba Lake during the warm seasons, especially in the central region on the lake, where the dissolved oxygen contents, with increase of the organic material, undergo depletion in low flow periods (Bendati, 2000). Another reason could be due to the higher rainfall during the winter, the water input and thus outflow from Guaíba could be higher than in other seasons and, consequently, the metal content would be more diluted in the water. Campagna et al. (2008) found higher bioavailability metals level in the sediment of the Monjolinho River, São Paulo, Brazil, during the dry season, probably because of lower dilution of the pollutants. Anyway, in the Guaíba Lake, there is the necessity to asses the metal levels for more years to obtain the picture more clearly about the seasonal patterns of contamination in the species.

The date and local differences in the metal concentrations could be due to the size of the individuals sampled too. However, this hypothesis was rejected because the larger individuals were captured either in the north and south regions of Guaíba Lake in the colder seasons. Despite the detoxifying capacity of the individuals, the data about the organic material in the sediment and the quality of water discussed above certainly contributed to the potential bioavailability of the metals to $L$. obtusidens. These environmental conditions probably attracted the species to forage and, consequently, caused the individuals to remain more time in the central zone of the lake. However, there is little information about the biology and ecology of L. obtusidens (Agostinho et al., 2003). According to Zaniboni Filho and Schulz (2003), the species reproduces in the spring, migrating upstream in the rivers. Nothing is known in Guaíba Lake about the displacement capacity of the individuals, but according to field observations, this species moves on to the lake to forage, mainly in summer months, when lean individuals are captured. However, individuals are captured throughout the year in the lake, which indicates a certain adaptation to lentic environments. According to Agostinho et al. (2003), this species has a preference for semi-lotic habitats, and reproduces in the reservoirs. This ability affects the use of L. obtusidens as an indicator of spatial differences in the metal concentrations in Guaíba Lake. Möllerke et al. (2002) found higher levels of $\mathrm{Hg}$ in the Pimelodus maculatus (Pimelodidae) compared with $L$. obtusidens due to different feeding and movement habits.

Contaminants in the fish can pose a health risk to the humans who consume them. According to Burger and Gochfeld (2005), there is no uniform source of guiding standards for most metal concentration in the fish tissue, except for mercury. In this work, the metal concentration levels were below the reference doses used (EPA, 2001 and Brazilian Ministry of Health, 1997), except for $\mathrm{Zn}$ (RfD $15 \mathrm{mg} / \mathrm{kg}$, EPA 2001). Moreover, the dose of a toxic metal that one obtains from the fish depends on the quantity of fish consumed. The consumption rate used in this work was based on Watanabe et al. (2003) (0.03 $\mathrm{kg} /$ day). According to Santos et al. (2004), the fish consumption rate for the adult inhabitants of Rio de Janeiro City was about $3.4 \mathrm{~kg} /$ year. Subsistence of some communities along Guaíba Lake was based on fishing and those people probably consumed more fish products than most of the population. Burger et al. (2001) and Watanabe et al. (2003) found differences on fish consumption as a function of socioeconomic factors in the US territory and how this parameter was associated with the potential risk to human health. This study 
found that the consumption of L. obtusidens by the humans did not represent risks to their health. There is, however, the necessity of available with more attention the levels of $\mathrm{Cd}$ that were high in the liver of the species. Also, further studies are needed to better estimate the health risks to the general population and fishermen. Realistic data about the fish consumption (the mean size of the fish, for example) and monitoring of other species in Guaíba Lake (like Pimelodus maculatus) are necessary in order to improve the environmental and human health protection.

\section{ACKNOWLEDGEMENTS}

The authors are grateful to Cristiano Silveira and Paola Stumpf for their help in the laboratory and the field; to Zuleica Castilhos, Roseli Mollërke, Maria Teresa Raya Rodriguez, Ana Paula Maciel, Leandro da Silva Duarte and one anonymous referee for critiques and suggestions. This study was supported by FAPERGS (project 02/1291.3) and by CAPES through scholarship for the first author. S.M.H. is researcher by $\mathrm{CNPq}$ (304036/2007-2).

\section{RESUMO}

As concentrações dos metais $\mathrm{Cd}, \mathrm{Cr}, \mathrm{Cu}$ e $\mathrm{Zn}$ foram determinadas para os tecidos muscular e hepático de Leporinus obtusidens no sul do Brasil. Durante o ano de 2003, 54 indivíduos foram capturados em três locais ao longo do Lago Guaíba (norte, centro e sul). Neste estudo verificamos se havia diferenças entre os locais de amostragem e as épocas do ano nas concentrações de metais nos tecidos analisados, bem como relação entre a concentração do metal e tamanho e sexo dos indivíduos. O risco para o consumo humano também foi avaliado. A concentração média $(\mu \mathrm{g} / \mathrm{g})$ dos metais foi maior no fígado do que no músculo para todos os metais: $[\mathrm{Cd}]=$ $2,32 \gamma^{\lambda} ;[\mathrm{Cr}]=0,08+;[\mathrm{Cu}]=30,82 q$ e $[\mathrm{Zn}]=$ 97,77 . . Os resultados apresentaram diferenças significativas entre os locais (região central do lago com as maiores concentrações) e épocas do ano (meses de primavera e verão) para todos os metais, exceto Cr. Diferenças entre os sexos também foram detectadas, para $\mathrm{Cd}$ e $\mathrm{Zn}$, e relações com o tamanho dos indivíduos para $\mathrm{Cu}$ e $\mathrm{Zn}$. Os níveis encontrados no tecido muscular não oferecem riscos ao consumo da espécie.

\section{REFERENCES}

ABNT (2005), NBR ISO/IEC 17025: Requisitos gerais para a competência de laboratórios de ensaio $e$ calibração. $2^{\mathrm{a}}$ ed.

Adeyeye, E. T., Akingugha, N. J., Fesobi, M. E. and Tenabe, V. O. (1996), Determination of some metals in Clarias gariepinus (Cuvier and Vallencienness), Cyprinus carpio (L) and Oreochromis niloticus (L) fishes in a polyculture fresh water pond and their environments. Aquaculture, 147, 205-214.

Agostinho, A. A., Gomes, L. C., Suzuki, H. I. and Júlio Jr, H. F. (2003), Migratory fishes of the upper Paraná River Brazil. In- Migratory Fishes of South America, ed. J. Carolsfeld, B. Harvey, C. Ross and A. Baer. International Development Research Centre, Ottawa, pp.19-98.

Allen, P. (1994), Mercury accumulation profiles and their modification by interaction with cadmium and lead in the soft tissues of the cichlid Oreochromis aureus during chronic exposure. B. Environ. Contam. Tox., 53, 684-692.

Allen-Gil, S. M. and Martynov, V. G. (1995), Heavy metal burdens in nine species of freshwater and anadromous fish from the Pechora River, Northern Russia. Sci. Total Environ., 160/161, 653-659.

Al-Yousuf, M. H., El-Shahawi, M. S. and Al-Ghais, S. M. (2000), Trace metals in liver, skin and muscle of Lethrinus lentjan fish species in relation to body length and sex. Sci. Total Environ., 256, 87-94.

Andres, S., Ribeyre, F., Tourencq, J. N. and Boudou, A. (2000), Interspecific comparison of cadmium and zinc contamination in the organs of four fish species along a polymetallic polution gradient (Lot River, France). Sci. Total Environ., 248, 11-25.

Bendati, M. M., Schwarzbach, M. S., Maizonave, C. R., Almeida, L. B. and Bringhenti, M. L. (2000), Avaliação da qualidade da água do lago Guaíba (Rio Grande do Sul, Brasil) como suporte para a gestão da bacia hidrográfica. Paper presented at XXVII Congresso Interamericano de Engenharia Sanitária e Ambiental, São Paulo, ABES, pp. 20.

Bidone, E.D., Castilhos, Z.C., Santos, T.J.S., Souza, T. M. C. and Lacerda, L. D. (1997), Fish contamination and human exposure to mercury in Tartarugalzinho River, Northern Amazon, Brazil. A screening approach. Water Air Soil Pollut., 97, 9-15.

Brazilian Ministry of Health (1997), Decreto $N^{o} 55871$ de 26 de março de 1965. Legislação Federal do setor de saúde, 2, Brasília, pp. 498-545.

Bryan, G.W. and Langston, W. J. (1992), Bioavailability, accumulation and effects of heavy metals in sediments with special reference to the 
United Kingdom estuaries: a review. Environ. Pollut., 76, 89-95.

Burger, J. and Gochfeld, M. (2001), Heavy metals in commercial fish in New Jersey. Environ. Res., 99, 403-412.

Burger, J., Gaines, K. F. and Gochfeld, M. (2001), Ethnic differences in risk from mercury among Savannah River fishermen. Risk Anal., 21, 533-544.

Burger, J., Gaines, K.F., Boring, C.S., Stephens, W.L., Snodgrass, J., Dixon, C., McMahon, M., Shukla, S., Shukla, T. and Gochfeld, M. (2002), Metal levels in fish from the Savannah River: potential hazards to fish and other receptors. Environ. Res., 89, 85-97.

Campagna, A. F., Fracácio, R., Rodrigues, B. K., Eler, M., Fenerich-Verani, N. and Espíndola, E. L. G. (2008), Analyses of the sediment toxicity of Monjolinho River, São Carlos, São Paulo State, Brazil, using survey, growth and gil morphology of two fish species (Danio rerio and Poecilia reticulata). Braz. arch. biol. technol., 51, 193-201.

Canli, M. and Atli, G. (2003), The relationships between heavy metal $(\mathrm{Cd}, \mathrm{Cr}, \mathrm{Cu}, \mathrm{Fe}, \mathrm{Pb}, \mathrm{Zn})$ levels and the size of six Mediterranean fish species. Environ. Pollut., 121, 129-136.

Canli, M. and Furness, R. W. (1993), Toxicity of heavy metals dissolved in seawater and influences and sex and size on metal accumulation and tissue distribution in the Norway lobster Nephrops norvegicus. Mar. Environ. Res., 36, 217-236.

Carpene, M. and Vasak, M. (1989), Hepatic metallothionein from goldfish (Carassius auratus). Com. Biochem. Phys., 92B, 463-468.

Castilhos, Z.C., Bidone, E. D. and Hartz, S. M. (2001), Bioaccumulation of mercury by tucunaré (Cichla ocellaris) from Tapajós River region, Brazilian Amazon: a field dose-response approach. Environ. Contam. Toxicol., 66, 631-637.

EPA-Environmental Protection Agency (2001), Integrated risk information system, USA. Available at http://www.epa.gov/iris (Access on 27, March 2004).

Evans, D. W., Dodoo, D. K. and Hanson, P. J. (1993), Trace element concentrations in fish livers: implications of variations with fish size in pollution monitoring. Mar. Pollut. Bull., 26, 329-334.

Farkas, A., Salánki, J. and Specziár, J. (2003), Age- and size-specific patterns of heavy metals in the organs of freshwater fish Abramis brama L. populating a lowcontaminated site. Water Res., 37, 959-964.

Fernandes, H. M., Bidone, E. D., Veiga, L. H. S. and Patchineelam, S. R. (1994), Heavy-metal pollution assessment in the coastal lagoons of Jacarepaguá, Rio de Janeiro, Brazil. Environ. Pollut., 85, 259-264.

Förstner, U. and Wittmann, G. T. W. (1981), Metal Pollution in the Aquatic Environment. SpringerVerlag, Berlin

Gbem, T. T., Balogun, J. K., Lawal, F. A. and Annune, P. A. (2001), Trace metal accumulation in Clarias gariepinus (Teugels) exposed to sublethal levels of tannery effluent. Sci. Total Environ., 271, 1-9.

Hartz, S. M., Silveira, C. M., Carvalho, S. and Villamil, C. (2000), Alimentação da piava, Leporinus obtusidens (Characiformes, Anostomidae) no Lago Guaíba, Porto Alegre, Rio Grande do Sul, Brasil. Pesq. Agrop. Gaúcha, 6, 145-150.

Hellou, J., Warren, W. G., Payne, J. F., Belkhode, S. and Lobel, P. (1992), Heavy metals and other elements in three tissues of cod Gadus morhua from the Northwest Atlantic. Mar. Pollut. Bull., 24, 452458.

Hogstrand, C. and Howx, C. (1991), Binding and detoxification of heavy metals in lower vertebrates with reference to metallothionein. Com. Biochem. Phys., 100C, 137-141.

Jargensen, L. A. and Petersen, S. (1994), Trace metals in fish used for time trend analysis and as environmental indicators. Mar. Pollut. Bull., 28, 2432.

Jordão, C. P., Pereira, J. L. and Jham, G. N. (1997), Chromium contamination in sediment, vegetation and fish caused by tanneries in the State of Minas Gerais, Brazil. Sci. Total Environ., 207, 1-11.

Kalay, M. and Canli, M. (2000), Elimination of essential $(\mathrm{Cu}, \mathrm{Zn})$ and nonessential $(\mathrm{Cd}, \mathrm{Pb})$ metals from tissues of a freshwater fish Tilapia zillii following an uptake protocol. Tr. J. Zool., 24, 429436.

Kargin, F. and Erden, C. (1991), Accumulation of copper in liver, spleen, stomach, intestine, gill and muscle of Cyprinus carpio. Tr. J. Zool.,15, 306-314.

Khan, T. and Weis, J.S. (1993), Bioaccumulation of heavy metals in two populations of Mummichog (Fundulus leteroclitus). B. Environ. Contam. Tox., 51, 1-5.

Laybauer, L. (2002), Estudo do risco ambiental e da dinâmica sedimentológica e geoquímica da contaminação por metais pesados nos sedimentos do lago Guaíba, Rio Grande do Sul, Brasil. PhD Thesis, Universidade Federal do Rio Grande do Sul, Porto Alegre, Brasil

Laybauer, L. and Bidone, E. D. (2001), Caracterização textural dos sedimentos de fundo do lago Guaiba (sul do Brasil) e sua importância em diagnósticos ambientais. Pes. Geociências, 28, 13-26.

Linde, A. R., Sánchez-Galán, S., Izquierdo, J. I., Arribas, P., Marrañón, E. and García-Vásquez, E. (1998), Brown trout as biomonitor of heavy metal pollution: effect of age on the reliability of the assessment. Environ. Res. Section B, 40, 120-125.

Manly, B. F. J. (1997), Randomization, bootstrap and Monte Carlo methods in biology. Chapman and Hall, London

Marcovecchio, J. E. and Moreno, V. J. (1993), Cadmium, zinc and total mercury levels in the tissues of several fish species from La Plata River Estuary, Argentina. Environ. Monit. Assess., 25, 119-130. 
Mastala, Z., Balogh, K. V. and Salanski, J. (1992), Reliability of heavy metal pollution monitoring utilizing aquatic animal versus statistical evaluation methods. Arch. Environ. Cont. Tox., 23, 476-483.

Menegat, R., Porto, M. L., Carraro, C. C. and Fernandes, L. A. (1998), Atlas Ambiental de Porto Alegre. Editora da Universidade/UFRGS, Porto Alegre

Moiseenko, T. I. and Kudryavtseva, L. P. (2001), Trace metal accumulation and fish pathologies in areas affected by mining and metallurgical enterprises in the Kola Region, Russia. Environ. Pollut., 114, 285297.

Möllerke, R. O., Noll, I. B. and Santo, M. A. B. E. (2002), Níveis de mercúrio em piavas (Leporinus obtusidens) e em pintados (Pimelodus maculatus) do Lago Guaíba, Porto Alegre, Estado do Rio Grande do Sul, Brasil. Rev. Bras. Toxicol., 15, 93-97.

Möllerke, R. O., Noll, I. B., Santo, M. A. B. E. and Norte, D. M. (2003), Níveis de arsênio total como indicador biológico, na avaliação da qualidade do pescado (Leporinus obtusidens e Pimelodus maculatus) do lago Guaiba em Porto Alegre, RS, Brasil. Rev. Inst. Adolfo Lutz, 62, 117-121.

Phillips, D. J. H. (1977), The use of biological indicator organisms to monitor trace metal pollution in marine and estuarine environments - a review. Environ. Pollut., 13, 282-317.

Pillar, V. D. (2004), MULTIV: multivariate exploratory analysis, randomization testing and bootstrap resampling. User's guide, v.2.3. Universidade Federal do Rio Grande do Sul, Porto Alegre, Sofwtare and manual available from http://ecoqua.ufrgs.br.

Pillar, V. D. and Orlóci, L. (1996), On randomization testing in vegetation science: multifactor of relevé groups. J. Veg. Sci., 7, 585-592.

Raya-Rodriguez, M. T. and Mozeto, A. A. (1995), Elementos-traço em compartimentos bióticos da lagoa Emboaba, Osório, RS. Bol. Inst. Bioc., 54, 5774.

Rocha, A. A., Pereira, D. N. and Pádua, H. B. (1985), Produtos de pesca e contaminantes químicos na água da represa Billings, São Paulo, Brasil. Rev. Saúde Pub., 19, 401-410.

Rodrigues, M. L. K. and Formoso, M. L. L. (2005), Exposure to selected heavy metals through water ingestion in an area under the influences of tanneries. Environ. Geochem. and Health, 27, 397-408.

Roméo, M., Siau, Y., Sidoumou, Z. and GnassisBarelli, M. (1999), Heavy metal distribution in different fish species from the Mauritania coast. Sci. Total Environ., 232, 169-175.

Santos, E. E., Lauria, D. C. and Porto da Silveira, C. L. (2004), Assessment of daily intake of trace elements due to consumption of foodstuffs by adult inhabitans of Rio de Janeiro city. Sci. Total Environ., 327, 6979.
Silvano, J. and Raya-Rodriguez, M. T. (2003), Evaluation of metals in water, sediment and fish of Azul lake, an open-air originally coalmine (Siderópolis, Santa Catarina state, Brazil). Acta Limnol. Bras., 15, 71-80.

Sternlieb, I. (1980), Copper and the liver. Gastroenterology, 78, 1615-1628.

Swales, S., Storey, A. W., Roderick, I. D., Figa, B. S., Bakowa, K. A. and Tenakanai, C. D. (1998), Biological monitoring of the impacts of the Ok Tedi copper mine on fish populations in the Fly River system, Papua New Guinea. Sci. Total Environ., 214, 99-111.

Tomazelli, A. C., Martinelli, L. A., Avelar, W. E., Camargo, P., Fostier, A.-H., Ferraz, E., Krug, F. J., and Santos Jr., D. (2003), Biomonitoring of Pb and $\mathrm{Cd}$ in two impacted watersheds in Southeast Brazil, using the freshwater mussel Anodontites trapesialis (Lamarck, 1819) (Bivalvia: Mycetopodidae) as a biological monitor. Braz. arch. biol. technol., 46, 673-684.

Ünlu, E., Akba, O., Sevim, S. and Gümgüm, B. (1996), Heavy metal levels in mullet, Liza abu (Heckel, 1843) (mugilidae) from the Tigris river, Turkey. Fresen Environ. Bull., 5, 107-112.

Vari, R. and Malabarba, L. R. (1998), Neotropical Ichthyology: an overview. In- Phylogeny and Classification of Neotropical Fishes, ed. L. R. Malabarba, R. Reis, R. Vari, Z. M. Lucena, C. A. Lucena. EDIPUCRS, Porto Alegre

Watanabe, K. H., Desimone, F. W., Thiyagarajah, A., Hartley, W. R. and Hindrichs, A. E. (2003), Fish tissue quality in the lower Mississippi River and health risks from fish consumption. Sci. Total Environ., 302, 109-126.

Yilmaz, A.B. (2003), Levels of heavy metals ( $\mathrm{Fe}, \mathrm{Cu}, \mathrm{Ni}, \mathrm{Cr}, \mathrm{Pb}$ and $\mathrm{Zn}$ ) in tissue of Mugil cephalus and Trachurus mediterraneus from Iskenderun Bay, Turkey. Environ. Res., 92, 277-281.

Zaniboni Filho, E. and Schulz, U. H. (2003), Migratory fishes of the Uruguay River. In- Migratory Fishes of South America, ed. J. Carolsfeld, B. Harvey, C. Ross, A. Baer. International Development Research Centre, Ottawa, pp.157-194.

Zar, J. H. (1984), Bioestatistical analysis. Prentice-Hall, New Jersey

Zayed, M. A., El-Dien, F. A. N. and Rabie, K. A. (1994), Comparative study of seasonal variation in metal concentration in River Nile sediment, fish and water by atomic absorption spectrometry. Microchem. J., 49, 27-35.

Received: August 25, 2006; Revised: June 13, 2007; Accepted: July 04, 2008. 